\title{
異構造マスタスレーブマニピュレータにおける マルチ操作モードと炎の作業性
}

\author{
松日楽 信 人* 朝 倉 誠* 番 場 弘 行*

\begin{abstract}
Multi-control Modes for a Master-slave Manipulator with Different Configurations and Its Maneuverability
\end{abstract}

\author{
Nobuto Matsuhira*, Makoto Asakura* and Hiroyuki Bamba*
}

\begin{abstract}
The new master-slave control method is proposed on multi-control modes for a master-slave manipulator with different configurations. A virtual internal model following control is applied to position symmetrical bilateral control. In our method, a master-slave control mode (MS-mode), a joystick control mode (JS-mode), a master arm offset mode (OM-mode), and a servo hold mode (LK-mode) are able to be realized by operating the desired output values of the virtual internal models in a common control algorithm. There is compliant characteristic between the master and slave models. In the result of evaluation experiments between the MS-mode and the JS-mode, although the MS-mode is superior to the JS-mode in manipulating a fine task, our JS-mode is found to be useful to carry out such a task compared with a conventional JS-mode which only directs the rates for the slave arm. In the JS-mode, the slave arm moves to the position where the reaction force of the slave arm and the operating force of the master arm are balanced. Thus, it is possible either to control an overload for an object and to control the contact force. The validity of the proposed method is verified.
\end{abstract}

Key Words: Master-slave Manipulator, Virtual Internal Model, Symmetrical Bilateral Control, Multi-control Modes, Maneuverability

\section{1. は じめに}

マスタスレーブマニピュレータ (MSM) は原子力施設内や宇 宙, 深海など人間が容易に近づけない場所での作業に，人間が 離れた場所から遠隔で作業を行うためのロボットである。ま た，その作業内容は非定型である場合が多く，人間の臨機応変 な判断が必要であり，なかなか自動化は困難である。MSM は 当初, マスタアーム (以下マス夕) とスレーブアーム（以下ス レーブ）との形状が相似形であったが, 計算機の能力が向上し たため，マスタとスレーブの形状が異なる場合でも，実時間で の座標変換演算が可能となり, いわゆる異構造 MSM の研究 が行われるようになった[1][2].筆者らも MSM の操作性 向上のため異構造 MSM の研究開発を行ってきた 3 ]. 異構 造 MSM では，計算機が介在しているので，高機能化が容易 である。これまでにも，通常のマスタスレーブ制御である位置 指令モードと, 従来からよくロボットの操緹に使用されてきた ジョイスティックによる速度指令モードの両方の使い方が可能

原稿受付 1994 年 10 月 27 日

*(株)東芝 研究開発センター

*Toshiba Corporation Research and Development Center
であるものが多い[4]〜[9]. 本論文では前者をマスタスレー ブモード (MS モード), 後者をジョイスティックモード (JS モ ード）と呼ぶことにする. JS モードではマスタを基本姿勢でサ 一ボロックするか, 復元力を持たせることによりジョイスティ ック的に用いることが多い.このほかに, 異構造ではマス夕と スレーブの動作範囲が異なるために，マスタの原点をオフセッ トし，スレーブの動作範囲をカバーする機能も必要である.

これまで, JS モードに関しては，単にスレーブ先端に速度 指令を与えるだけであったので, 拘束を伴うような細かな作業 は困難であった。あるいは，コンプライアンス制御をスレーブ 側に取り入れることも考えられるが，コンプライアンス制御で あっても, 変位が大きいと対象物に与える負荷も大きくなり, 場合によっては作業性が低下する.

従来, 異構造 MSM の研究では, そのシステム構成や制御 手法についての報告はあるが，操作モードの実現方法に関する 報告はない。異構造 MSM においてはMS モードと JS モード は重要な操作モードであるに関わらず, 個々に議論されてき た。筆者らは，仮想内部モデルを用いたバイラテラル制御構成 により，これらの操作モードを統一的に扱う制御方法を提案す る.さらに, MS モードと JS モードについて作業性評価実験 
を行い，本制御方式の有効性を確認するとともにJS モードの 作業性向上を確認したので，これらについて報告する.

\section{2. 提案するバイラテラル制御方式}

\section{1 仮想内部モデルを用いた対称型バイラテラル制御}

古田・小菅ら [10]は MSM に仮想内部モデル追従制御を適用 し，動特性を任意に設定できることを示した．内部モデルを用 いてスレーブ反力をマスタに伝えているため過渡的には正確な バイラテラルを実現できないが, 衝突時や接触時の安定性に優 れている。 また，文献[10]では具体的な例として仮想内部モデ ルを用いた力帰還型バイラテラル制御が示されている．本研究 では，対称型バイラテラル制御に仮想内部モデルを用いた。従 来の対称型では摩擦や慣性の補償ができず，マス夕の操作性が 悪いという問題があったが，理想的な対称型を内部モデルで構 成し，その規範出力に追従動作させることにより解決される. 本方式は宮崎・萩原 [11]の並列型や井上ら [12]のインピーダン ス制御にも類似だが，内部モデルを用いている点やマスタ・ス レーブ間にコンプライアンスがある点で異なる，すなわちマス タ，スレーブそれぞれに仮想内部モデルを設定し，モデル間で 対称型制御を行い，それらの運動に実際のマスタ、スレーブを 追従させるものである. マスタ, スレーブのモデルのパラメー 夕を変えることにより，操作性・作業性を調整できるので，異 構造 MSM には適していると考えられる．Fig. 1 に仮想内部 モデル追従型制御のブロック図を, Fig. 2 に仮想内部モデルに よる対称型バイラテラル制御のブロック図をそれぞれ示す.

このとき, 仮想内部モデルの運動 $(X)$ は次のように表せる.

$$
\begin{gathered}
F_{m}-\tau=M_{m} \ddot{X}_{m}+B_{m} \dot{X}_{m} \\
K f F_{s}+\tau=M_{s} \ddot{X}_{s} / K p+B_{s} \dot{X}_{s} / K p \\
\tau=K c\left(X_{m}-X_{s} / K p\right)+K v\left(\dot{X}_{m}-\dot{X}_{s} / K p\right)
\end{gathered}
$$

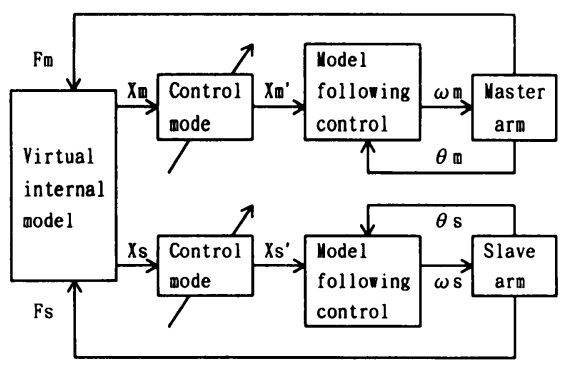

Fig. 1 Proposed MSM control

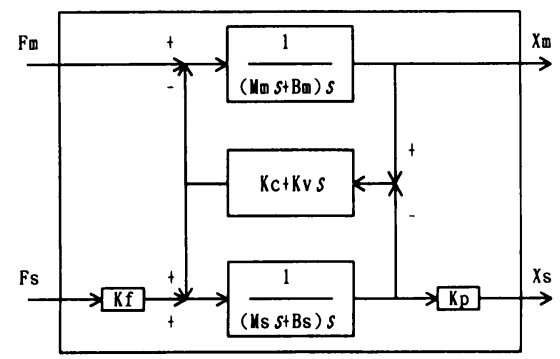

Fig. 2 Symmetrical bilateral control using virtual internal models
ここで, $\tau:$ マスタ・スレーブ間の結合力,

$F:$ 操作力/反力,

$M, B$ : 仮想内部モデルの質量および粘性係数,

$K c, K v$ : 仮想内部モデル間の対称型制御の位置ゲインおよ び速度ゲイン,

$K f, K p$ : 力反射率および運動伝達比

を表す。なお，添字 $m, s$ はそれぞれマスタ，スレーブを表し ている。.また, Fig.1において, $\omega$ は実際のアームへの目標関 節角速度, $\theta$ は実際のアームの関節角度, さらに $X^{\prime}$ はモデル の運動値にオフセット補正した出力值である。これについては 次章で説明する. 目標位置追従制御器では目標位置を目標関節 角度に変換し，追従制御を行っている.

\section{2 安定性の検討}

系の安定性は内部モデル出力への追従制御特性に依存する が，ここでは追従帯域が十分に高いとし，内部モデルの安定性 問題として簡単な検討を行う. 内部モデルは Fig. 3 に示すよ うに機械的な対称型バイラテラル構成を取っているので，受動 性原理が成り立ち安定である。

まず，スレーブが非拘束のときの運動を考える．簡略化のた め $K f=K p=1$ とする. 式 (1) ( 3$), F_{s}=0$ より, 定常状態 では,

$$
\begin{aligned}
\dot{X}_{s}= & (K v s+K c) F_{m} /\left\{\left(M_{m} s+B_{m}\right)\left(M_{s} s+B_{s}\right) s\right. \\
& \left.+(K v s+K c)\left(M_{m} s+B_{m}+M_{s} s+B_{s}\right)\right\} \\
& \rightarrow F_{m} /\left(B_{m}+B_{s}\right)
\end{aligned}
$$

となる。したがって，スレーブの速度はマスタ操作力に比例す る速度に収束する。

スレーブが対象物と接するような拘束時は，対象物をバネ定 数 $K w$ ，変位を $X w$ で表すと対象物に加わる力 $F w$ は，次式 の関係となる。

$$
F w^{\prime}=K w X w, \quad F_{s}=-F w
$$

また，十分追従性が高いとして定常状態で $X S=X w$ とすれ ば,

$$
\begin{aligned}
X w= & (K v s+K c) F_{m} /\left\{\left(M_{m} s^{2}+B_{m} s\right)\left(M_{s} s^{2}+B_{s} s+K w\right)\right. \\
& \left.+(K v s+K c)\left(M_{m} s^{2}+B_{m} s+M_{s} s^{2}+B_{s} s+K w\right)\right\} \\
& \rightarrow F m / K w
\end{aligned}
$$

となる。式(5)（6)より

$$
F_{s}=-K w X w=-F_{m}
$$

したがって，スレーブに加わる力とマスタにかける力は釣り合 う。また，このときの変位は次式となる．

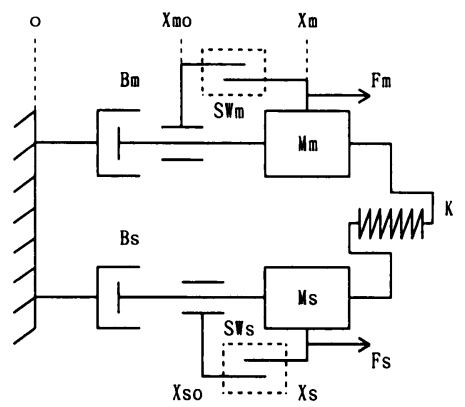

Fig. 3 Mechanical MSM model with mode change switches 


$$
X w=K c X_{m} /(K c+K w)
$$

次に，対象物の剛性の影響を考える。式(7)（8)より

$$
\begin{aligned}
F_{m} & =K w X w=K c K w X_{m} /(K c+K w) \\
& =K w X_{m} /(1+\alpha)=K c X_{m} \alpha /(1+\alpha)
\end{aligned}
$$

ここで, $\alpha=K w / K c$ とした.

$K c \gg K w$ の対象物であれば，マスタに対象物の剛性が正確に 伝わる. また， $K w$ が大きくなるとアームの追従帯域が十分に 高いという前提が成立しなくなり，力制御の安定性が問題とな るが，本制御方式の場合， $K c \ll K w$ では,

$$
F_{m}=K c X_{m}
$$

となり, マスタ・スレーブ間の介在コンプライアンスにより, 安定性を保つことができる。

\section{3. マルチ操作モード}

\section{1 操作モードの分類}

異構造の MSM では，その構造が異なるためはもちろん， そのほか計算機が介在するためにいろいろな操作モードが付加 できる，異構造 MSMでよく用いられているのは，位置を対 応させる通常の MS モードとジョイスティック的に速度指令 を与える JS モードである。一般には，力感覚の必要な細かな 作業は前者で, 大体の位置操作は後者でと使い分けている. ま た，マスタはスレーブよりも一般に小さいので，動作範囲を対 応させる必要がある. マスタからスレーブへの運動伝達比を変 えるのも一案ではあるが, 伝達比を大きくとると細かな操作に は不適である，そこで，マスタが先に動作限界に達したら，マ スタの原点を移動しオフセットを与え, 再び作業を継続するこ とでスレーブの広い動作範囲をカバーすることができる．この 操作をマスタオフセットモード (OM モード) と呼び, さらに 起動待機時の状態をサーボロックモード（LK モード）と呼ぶ と，おもに 4 つの操作モードに分類される.

このほかにスレーブの運動方向やコンプライアンスに異方性 を持たせたり [5], 拘束面を持たせたり [7], マスタからスレ ーブへの対応点を変更する機能 $[9]$ なども提案されているが, これらはスレーブの制御に関するものであり, 操作モードとし て大きく異なるものではない.

\section{2 マルチ操作モードの実現方法}

Fig. 1 の制御方式では仮想内部モデルの運動出力值に実際の アームが追従するので，操作モードの切り換えを行うのに出力 值を操作することによりマルチ操作モードを実現することがで きる．すなわち， 2.2 節で述べたように仮想内部モデルを使う ことにより，操作力でスレーブに速度指令を与えることができ るので, MS モードと JS モード, さらに OM モードやLK モ ードを，同じ制御系で切り換えることが容易にできる。これら

Table 1 Control modes

\begin{tabular}{r|c|c}
\hline & $S W_{m}$ & $S W_{s}$ \\
\hline MS-mode & OFF & OFF \\
JS-mode & ON & OFF \\
OM-mode & OFF & ON \\
LK-mode & ON & ON \\
\hline
\end{tabular}

は, Fig. 3 に示す原点オフセットスイッチ（SW）により，（1） マスタ，スレーブともに動くモード (MS)，（2 ）スレーブのみ 動くモード (JS)，（3) マスタのみ動くモード (OM)，（4)マス 夕，スレーブともにロックされるモード (LK)，とアームの動 作状態で Table 1 に示すように分類することができる. したが って，モード間の連続性を考慮してモデルの運動出力值にオフ セット処理をすれば良いことがわかる。

Fig. 3 の 1 自由度の MSM モデルを用いて具体的に説明す る. 仮想内部モデルは質量 $M$ ，粘性係数 $B$ とからなり，マス タモデルとスレーブモデルはバネ $K$ で結合されているものを 考える. 前述したように物理的には定常時, マスタとスレーブ はコンプライアンスの分変位して力が釣り合うモデルである.

さらに, このモデルにおいてマスタ, スレーブともに原点のオ フセットスイッチを設け，この ON/OFF により，4つのモー ドを切り換える.

ここで，位置追従系への目標位置は次のようになる．

$$
X^{\prime}= \begin{cases}X-X o & (\mathrm{SW}: \mathrm{OFF}) \\ X \text { const } & (\mathrm{SW}: \mathrm{ON})\end{cases}
$$

$X$ は内部モデルの出力位置, $X o$ は原点からのオフセット值を 表す。Xoは $\mathrm{SW}$ が $\mathrm{OFF}$ になる直前の $X o$ の值であり, 内部 モデルの位置と実際のアームの位置とを関係づける， $X$ const は SW が ON になる直前の $X^{\prime}$ 値で一定値となり, 目標位置 を保持し続け, その結果, 実際のアームはサーボロックされて 動かない.すなわち, SW は実際のアームの動作を停止, 連動 させるスイッチになっている. SW が ON (ロックされる)では $X o$ がモデルとともに相対位置 $X$ const を保って運動し, OFF (フリーとなる) では $X O$ に対してモデルは運動するものとす る.

たとえば，JS モードではマスタ原点 $\left(X_{m} O\right)$ が仮想内部モデ ルのマスタ $\left(X_{m}\right)$ とともに移動するので, マスタの相対位置は 変化せず，スレーブのみが動く速度指令モードが実現できる. 他も同様である。

\section{4. 操作モードによる作業性評価実験と考察}

次に，本制御方式で実現される MS モードと JS モードでの 動作実験を行った。 マスタはパンタグラフを用いた直交座標型 であり，方向による慣性の差が小さい，また，スレーブは朵長 自由度を有する 7 自由度のスマートなアームである [13]. 実験 に用いた MSM を Fig. 4 に示す.ここで, マスタ, スレーブ ともに手首関節の 3 軸は 1 点で交差しており, 位置・力の対応 点は手首関節とした。

とくに本制御方式では JS モードが特徴的なので, JS モード を中心に MS モードと比較しながら説明する.なお，JSモー ドでは操作性の観点から, 姿勢についてはMS モードとした ハイブリッド構成になっている。位置追従制御系としては PD 制御としている.

また，実験に用いた仮想内部モデルのパラメータを Table 2 に示す.

\section{1 MS モードでの特性実験}

スレーブハンドを機械的に固定してマスタを $Z$ (上下）方向 にMS モードで操作したときの, マスタ $(M)$ とスレーブ $(S)$ 
Table 2 Parameters of internal models

\begin{tabular}{|c|c|c|c|c|c|c|}
\hline & $x$ & $y$ & $z$ & roll & pitch & yaw \\
\hline$M_{m}$ & 1.0 & 1.5 & 1.5 & 2.2 & 1.8 & 1.4 \\
\hline \multirow[t]{2}{*}{$M_{s}$} & 0.5 & 1.2 & 1.2 & 1.8 & 2.0 & 1.4 \\
\hline & \multicolumn{3}{|r|}{$[\mathrm{kg}]$} & \multicolumn{3}{|c|}{$\left[10^{-3} \mathrm{kgm}^{2}\right]$} \\
\hline$B_{m}$ & 22 & 21 & 21 & 0.14 & 0.14 & 0.14 \\
\hline \multirow[t]{2}{*}{$B_{s}$} & 44 & 39 & 39 & 0.25 & 0.25 & 0.25 \\
\hline & \multicolumn{3}{|c|}{$[\mathrm{Ns} / \mathrm{m}]$} & \multicolumn{3}{|c|}{$[\mathrm{Nms} / \mathrm{rad}]$} \\
\hline \multirow[t]{2}{*}{$K c$} & 2.0 & 3.0 & 3.0 & 8.0 & 8.0 & 8.0 \\
\hline & \multicolumn{3}{|c|}{$\left[10^{3} \mathrm{~N} / \mathrm{m}\right]$} & \multicolumn{3}{|r|}{$[\mathrm{Nm}]$} \\
\hline \multirow[t]{2}{*}{$K v$} & 0.0 & 0.0 & 0.0 & 0.1 & 0.0 & 0.0 \\
\hline & \multicolumn{3}{|c|}{$[\mathrm{Ns} / \mathrm{m}]$} & \multicolumn{3}{|c|}{$[\mathrm{Nms} / \mathrm{rad}]$} \\
\hline
\end{tabular}

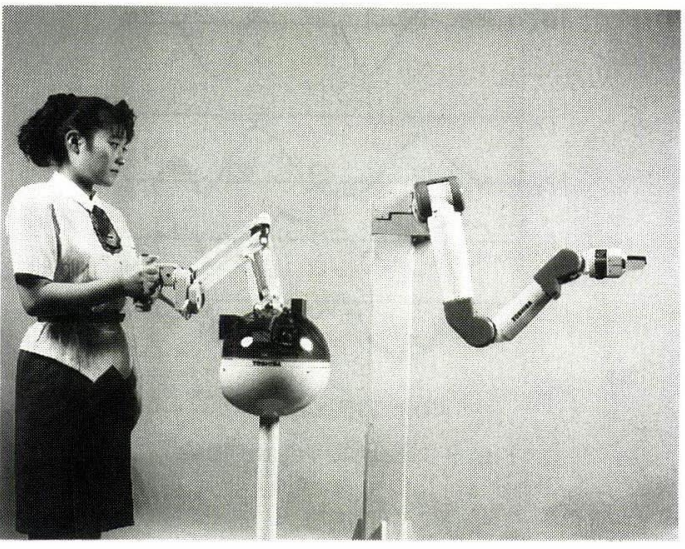

Fig. 4 Overview of MSM

のアームの変位 $(P z)$ と力 $(F z)$ を Fig. 5 $(\mathrm{a})$ に示す。マスタと スレーブの力はほぼ一致しているが, ハンドが拘束されている ためアームの運動にはマスタ・スレーブ間のコンプライアンス の効果が表れていることがわかる，比較のために，スレーブ側 を非拘束とした場合の運動を Fig. 5 ( b ) に示す. $100[\mathrm{msec}]$ 程 度の遅れがあるがスレーブがマスタに追従している。

\subsection{JS モードでの特性実験}

JS モードでの力特性について実験結果を Fig. 6, 7 に示す.

Fig. 6 はマス夕の操作力として, 力センサの入力に約 $10[\mathrm{~N}]$ の 信号を与えたものである. スレーブの正面 $10[\mathrm{~cm}]$ のころに は壁があるが, 衝突前は一定速度で動作し, 衝突したときの衝 撃力はすぐに減衰し，安定して接触しているのがわかる，接触 力はマスタ操作力に応じた荷重となっている。

たとえば，従来の速度指令では過大な力が対象物にかかるこ とは明らかであり，また，コンプライアンス制御を取り入れて も変位に応じて負荷がかかることになる，負荷を小さくするに はコンプライアンスをかなり大きくしなければならない.しか し，コンプライアンスが大きくなると，力が発生できず作業性 が低下する.

Fig. 7 はスレーブ手先を固定し， $Y$ (左右) 方向について，マ スタにかけた力とスレーブ先端での力をロードセルで測定した ものである。コンプライアンス制御をスレーブに適用したとき
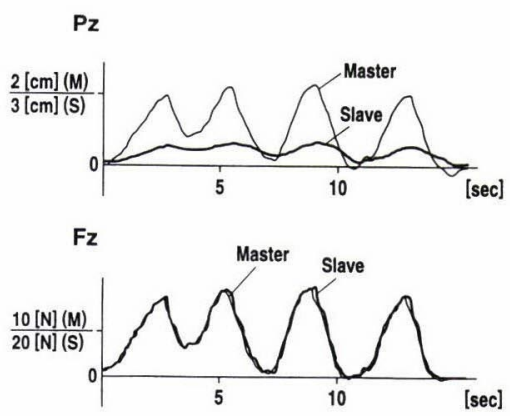

(a) Restraint

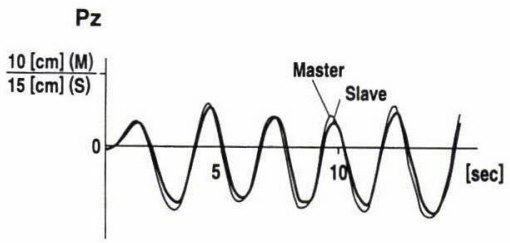

(b) Without restraint

Fig. 5 Motion response in MS-mode

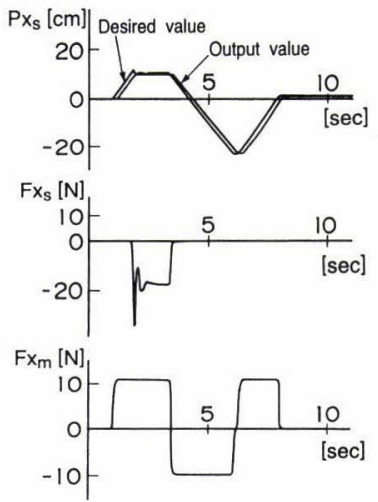

Fig. 6 Force response in JS-mode

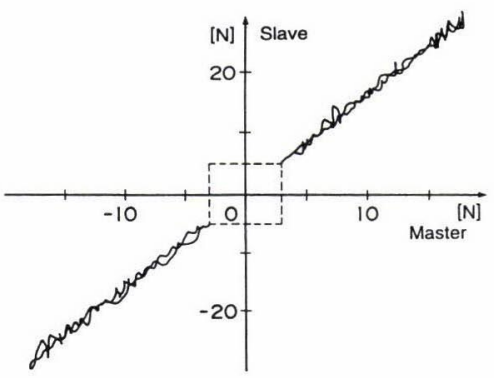

Fig. 7 Relationship between operational force and contact force in JS-mode

とは異なり，マスタ操作力とスレーブ反力とがほぼ比例してい る. 点線は不感带を示し，マスタ側 $3[\mathrm{~N}]$ ，スレーブ側 $5[\mathrm{~N}]$ とした。したがって，本 JS モードではマス夕操作でスレーブ 側での力をコントロールすることも可能である。

このように JS モードでは, スレーブは仮想内部モデルを用 いた対称型バイラテラル制御に基づき制御されているので, マ 


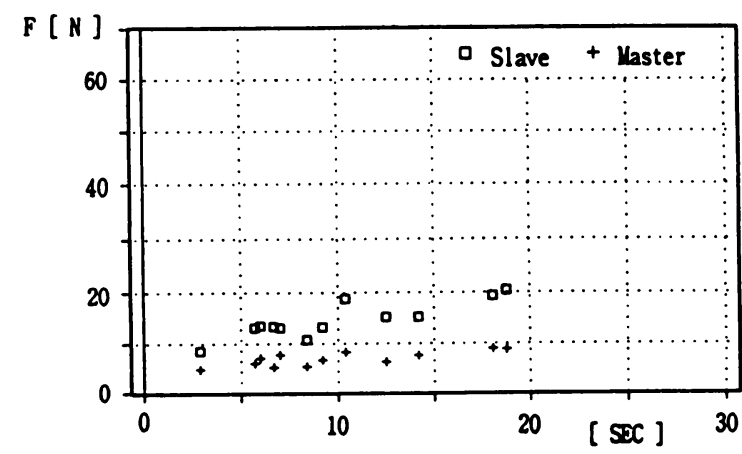

(a) MS-mode

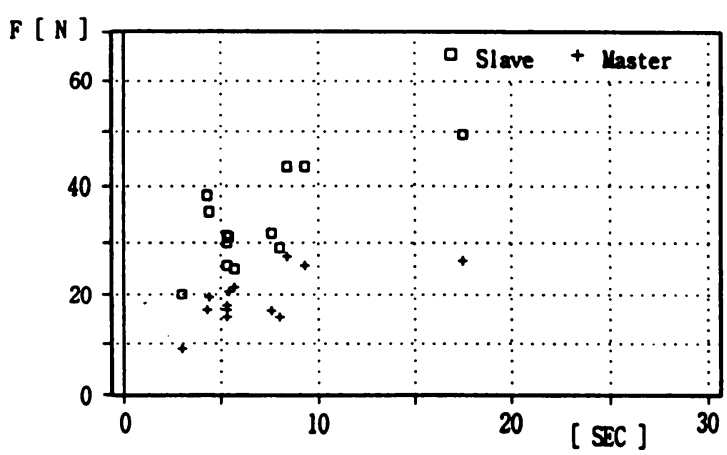

(b) JS-mode

Fig. 8 Peg-in-hole task

ス夕操作力に比例した速度で運動し, 対象物に接触するとスレ 一ブの反力はマス夕にかける力と対応する力で釣り合い，過負 荷を避けることができる.

\subsection{MS モードと JS モードによる作業性評価実験}

作業性評価実験として拘束的な作業であるピン捙入とハンド ル回しを MS モードとJSモードでそれぞれ行った。なお, MSモード時，力反射率，運動伝達比は並進で $50 \% ， 1: 1.5$, 姿勢で $20 \%, 1: 1$ とした，操作者は MSM 操作に熟練した 27 歳の男性である.

ピン挿入作業の結果を Fig. 8 に示す. ピン直径は $20[\mathrm{~mm}]$ であり，吵間は $0.02[\mathrm{~mm}]$ 以下である. $50[\mathrm{~mm}]$ 間隔の 3 つの 穴に対して交互に抜き差しした。ここでは挿入時に $X$ (前 後), $Y$ (左右), $Z$ (上下) 方向に働くマスタ, スレーブの力の うち各方向で最大值の和を代表値とした，横軸は作業時間であ る。それぞれ 12 回程度繰り返し実験した.MS モードの方が 負荷が小さく，作業時間が長い傾向がある，平均でみるとスレ ーブにかかる力はMSモード $(14.6[\mathrm{~N}])$, JS モード (33.4[N]) でMS モードの方が約 $1 / 2$, 同様に作業時間は $10[\mathrm{sec}], 5.4[\mathrm{sec}]$ で約 2 倍であった.

次に，ハンドル回し作業の代表的な結果を Fig.9 に示す. ハンドルの直径は $22.5[\mathrm{~cm}]$ である．縦軸にスレーブの並進変 位と並進力，横軸に作業時間を示す。ここでもMS モードの 方がハンドルに与える負荷が小さく，作業時間が短い.

$2 つ の$ 作業ともにMS モードの方が負荷が小さくスムーズ に行えていることがわかる。 しかし，従来の速度指令を与える JS モードでは作業対象に大きな負荷がかかり，実際に作業が

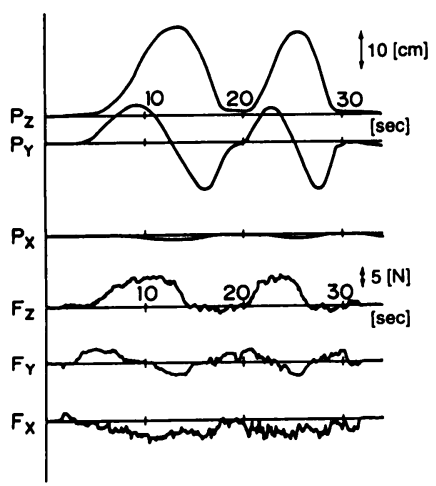

(a) MS-mode

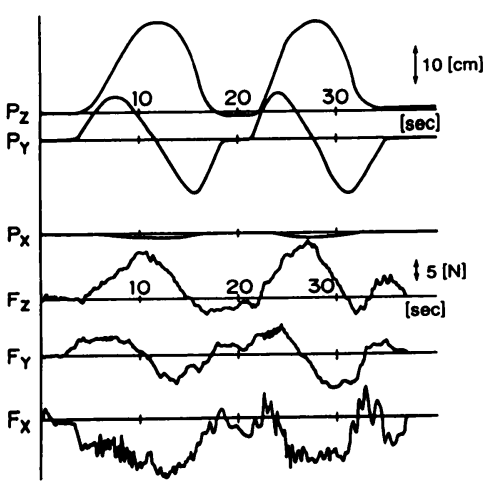

(b) JS-mode

Fig. 9 Handle rotate task

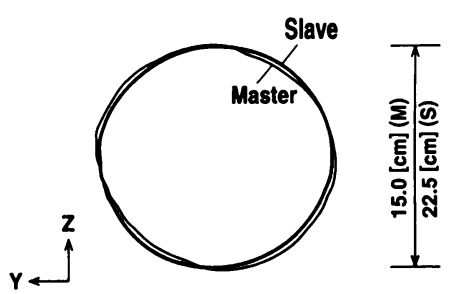

Fig. 10 Trajectories of handle rotate task in MS-mode

できなかったことを考えると，本JSモードにおいては大幅に 作業性が向上したと言える。 また，ピン挿入で時間的に JS モ 一ドが優るのは，位置决めの操作量（移動量）に関係している と考えられる. ピン挿入では操作量が少なく，押し付けるだけ でならい動作によりスムーズに挿入されるので速い．MS モー ドでは，力を感じながら位置を合わせているので，その分若干 時間がかかる，一方，ハンドル回しではある程度の誤差は許容 できるものの軌道生成のための操作量が多いので MS モード よりも位置決めのために時間がかかったと言える，MSモード でも円軌道の生成は難しいが，バイラテラルとなっているため に逆にスレーブ側から動かされ軌道が生成されやすい。なお， 位置指令型の MS モードの方が速度指令型の JS モードよりも 位置決め性において優れていることは，すでに実験により確認 している[9].

Fig. 10 にハンドル回しにおける MS モードでのマスタとス レーブでの軌跡を示す．スレーブの軌跡はハンドルで拘束され 
ているので，ほぼ直径 $22.5[\mathrm{~cm}]$ のとなっている。マスタ側 ではコンプライアンスの影響により，多少歪んでいるが，滑ら かに操作できていることがわかる。ママタからスレーブへの運 動伝達比も設定通り $(K p=1.5)$ に再現されている. 以上より, ピン挿入，ハンドル回し作業ともに，2つの操作モードにより 安定に作業が実現でき，本制御法の有効性が確認された。

\section{5. ま と め}

異構造 MSM において，仮想内部モデルを用いた対称型バ イラテラル制御を採用し，マルチ操作モードを実現する制御方 式を提案した。 その結果, 以下のことが確認された。

(1) MS モード, JS モード, マスタオフセットモード, サ ーボロックモードの 4 つの操作モードを共通の制御系 で切り換えることが可能となった。

（2）本制御方式ではマスタ・スレーブモデル間にコンプライ アンスが介在した特性を有し, MSモード, JSモード ともに拘束時の作業においても安定に作業が実現でき た.

（3）MSモードとJS モードによる作業性評価実験の結果, 接触を伴うような繊細な作業にはMS モードの方が対 象物に与える負荷が小さく優れているが，JS モードで も作業が可能であることがわかった。

(4) JS モードではスレーブはマスタ操作力とスレーブ反力 が釣り合う位置へ運動するので対象物に無理な力がか からない. また，スレーブと対象物との接触力をマス 夕操作によりコントロールすることも可能である.

以上，異構造 MSM の代表的な操作モードを統一的に扱う 制御方法およびその作業性の実験結果について示した。これら の操作モードを作業内容によって切り換えることで, 効率よく
作業を実行できるものと期待される。今後は，より操作性の優 れた遠隔操作システムの構築を目指して行く予定である.

\section{参 考 文 献}

[1] A. Bejczy and J. K. Salisbury: "Kinesthetic coupling between operator and remote manipulator," Proc. of the International Computer Technology, ASME, pp. 197-211, 1980.

２］新井, 中野：“異構造マニピュレータ間に㧍けるバイラテラルマスタ スレイブ制御”, 日本ロボット学会誌, vol. 4, no. 5, pp. 469-479, 1986.

[3] 松日楽：“異構造マスタスレーブマニピュレータ”, 計測自動制御学会 第 18 回ロボット工学部会研究会資料, pp. 1-10, 1992.

[4]戸田, 町田, 岩田, 川田：“宇宙用マスタ・スレープ・マニピュレータ・ システムの開発”, 日本航空宇宙学会誌, vol. 35, no. 406, pp. 546-553, 1987.

[5] 青木, 岩本, 中島, 山本, 住谷：“スマートマニピュレータにおける座標 変換演算一各種作業モードの記述一”, SAIRAS 88, pp. 11-14, 1988.

［6] 山脇, 胡間, 津田：“宇宙ステーション用リモートマニピュレータシス テム”, 東芝レビュー, vol. 44, no. 9, pp. 710-714, 1989

[7]渡辺, 内山：“宇宙実験用テレオペレーションシステム”, 日本ロボッ 卜学会誌, vol. 7, no. 6, pp. 759-764, 1989.

[8] 和気, 向田, 望月: “架空配電作業用マニピュレータシステムの開発 ( 1)”, 第 8 回日本ロボット学会学術講演会, pp. 1023-1024, 1990.

[9] 松日楽, 朝倉, 番場：“異構造マスタスレーブマニピュレータの作業性 とその評価実験”, 日本ロボット学会誌, vol. 12, no. 1, pp. 149-154, 1994.

[10］古田, 小菅, 塩手, 秦野：“仮想内部モデルに基づくマスタスレイブマ ニピュレータの制御”, 計測自動制御学会論文集, vol. 24, no. 2, pp. 70 $76,1988$.

[11] 宮崎, 荻原：“バイラテラル・マスタ・スレーブ・マニピュレータの並 列型制御方式”, 日本ロポット学会誌, vol. 7, no. 5, pp. 46-52, 1989.

[12] 井上, 舘, 荒井: “マスタスレーブ・マニピュレータのインピーダンス 制御の一方法”, 日本ロポット学会誌, vol. 10, no. 4, pp. 490-500, 1992.

[13] 松日楽, 朝倉, 番場, 植之原: “高性能マスタスレーブマニピュレータ の開発”, 日本ロボット学会第 2 回ロボットシンポジウム予稿集, pp. 145-149, 1992.

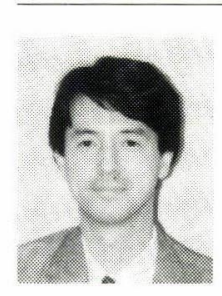

松日楽信人 (Nobuto Matsuhira)

1956 年 9 月 9 日生. 1980 年東京工業大学機械物理 工学科卒業. 1982 年同大学大学院修士課程（機械 物理工学専攻) 修了. 同年(株) 東芝入社. マスタス レーブマニピュレータなど遠隔操作ロボットの研 究開発に従事. 現在, 研究開発センター, 機械・エ ネルギー研究所, 主任研究員. 日本機械学会, 計 測自動制御学会の会員.

(日本ロボット学会正会員)

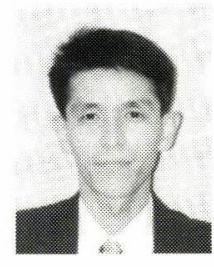

番場弘行 (Hiroyuki Bamba)

1965 年 2 月 7 日生. 1983 年宮城県工業高等学校卒 業. 同年(株)東芝入社. 現在, 研究開発セン夕 一, 機械・エネルギー研究所にてマスタスレーブマ ニピュレータおよび宇宙関連機器などの研究開発 に従事. 日本機械学会の会員.

（日本ロボット学会正会員）

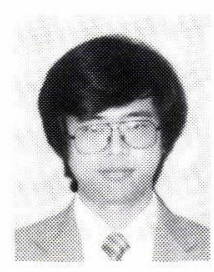

朝倉 誠（Makoto Asakura）

1959 年 7 月 17 日生. 1983 年慶應義塾大学電気工 学科卒業. 1986 年同大学大学院修士課程 (電気工 学専攻) 修了。同年 (株) 東芝入社. ロボットの力制 御などの研究開発に従事. 現在, 研究開発セン夕 一, 機械・エネルギー研究所, 研究主務. 計測自動 制御学会の会員. 